\footnotetext{
特集、スポーツ医学

順天堂医学 $44(3)$ p. 249 253 (1998)
}

\title{
思春期のスポーツ障害**
}

\section{Overuse injuries in children and adolescents}

\author{
高 澤 晴 夫* \\ HARUO TAKAZAWA,M.D.
}

\section{はじめに}

発育期は年齢によって前期・中期・後期の 3 期 に分けられる. 小学生・中学生・高校生に相当す るが, 小学生高学年から中学生にかけては思春期 といわれ, 成長・発達のいちじるしい時期であ り, 個人個人の体格・体力・運動能力に大きな違 いがみられる1)。おなじ年齢であっても発育の程 度に差があるからである。スポーツ障害の発生に このことが大いに関係してくる.暦年齢ではなく， 発育年齢を考慮しなくてはならない，正確には骨 年齢を調べるのが良いが, 身長の成長速度曲線を 参考にするのが一般的とされている2).

スポーツ活動が身体にどのように影響している かを正しく知ることが思春期のスポーツでは重要 である。過労性スポーツ障害はランニング・ジャ ンプ・投球などで同じ動作を繰り返して行うこと がもとになって発生する. その部位は関節に近く， 筋腱の骨への付着部, 関節軟骨・骨などが特徴的 である ${ }^{3)}$ 。そのため，骨・軟骨が成長過程にある 年齢層に起こりやすい.

一方，スポーツでは相手との接触プレイ・ぶつ かり合う・転倒などで直接外力をからだに受けて 発生する急性外傷, その後遺症ともいえる陳旧性, あるいは慢性の外傷がある。思春期のスポーツ障

*横浜市スポーツ医科学センター

Yokohama Sports Medical Center, Kanagawa, Japan

**第285回順天堂医学会学術集会 [May 20, 1998 開催] [Sept. 9, 1998 原稿受領]
害では過労性の障害と外傷によって生じた障害の 両者について考える必要がある4).

\section{スポーツ外傷・障害の発生状況}

われわれのところで最近診察を行ったスポーツ 外傷・障害 189 例についての調査によれば 17 歳 以下は26例, $13.8 \%$ あった. 男子 17 例・女子 9 例で男子に多い. 年齢別では男子では 15 歳以上 が，女子では 13 歳以上がほとんどであった。部 位では膝関節が一番多く, 過労性障害では膝痛・ 腰痛が多く, オスグッド病・脊椎分離症が 1 例づ つあった。外傷では勒帯損傷が 2 例, うち 1 例は 前十字勒帯損傷であった。次いで足関節が7例で あり, 捻挫が 4 例, 踝部骨折が 3 例であった。 そ のほか, 反復性肩関節脱臼・时離断性骨軟骨炎な どは手術が適応であった（表-1）。

国体代表高校体操選手, 男子 18例 -女子 15例 に次いてのメディカルチェックで多少とも症状が 認められたものは, 男女とも腰痛が第 1 位であ り, 春椎分離症は男子 2 例・女子 1 例であった。 次いでは, 足関節痛・膝痛・手関節痛などの過労 性障害などであった．スポーツ外傷の後遺症によ るものは膝勒帯損傷・踝部骨折・时脱臼などであ り，いずれも選手活動には多少の支障をもたらし ていた（表-2）.

文部省の運動部活動のあり方に関する調査研究 5)によれば, 整形外科スポーツドクターに対し診

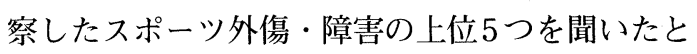
ころ, スポーツ外傷は足関節捻挫・膝周囲打撲 · 
表-1 成長期スポーツ選手のスポーツ外傷・障害 （17歳以下, 189例中 26例）

\begin{tabular}{|c|c|c|c|}
\hline & 男 & 女 & \\
\hline 腰痛 & 3 & 0 & 分離症 : 1 \\
\hline 膝痛 & 4 & 3 & オスグッド : 1 \\
\hline 滕蓋骨亜脱臼 & & 2 & \\
\hline 勒帯損傷 & 1 & 1 & ACL損傷：1 \\
\hline 足関節捻挫 & 2 & 2 & \\
\hline 踝部骨折 & 3 & 0 & \\
\hline 足関節痛 & 2 & 0 & \\
\hline 肩関節痛 & 0 & 1 & \\
\hline 反復性肩関節脱白 & 1 & 0 & \\
\hline 时痛 & 2 & 0 & 離断性骨軟骨炎：1 \\
\hline シンスプリント & 1 & 1 & \\
\hline 肉離れ & 1 & 0 & \\
\hline 計 & 20 & 10 & \\
\hline
\end{tabular}

挫傷・突き指が多く，スポーツ障害ではオスグッ ド病・野球肘・シンスプリントなどがおもなもの であった。

同じ調査で中学生・高校生で 1 週間以上練習を 休んだ経験の有無を聞いたところ，スポーツ外傷 は中学生で $20.0 \% \cdot$ 高校生で $33.4 \%$, スポーツ 障害は中学生で $12.6 \%$ ・高校生で $24.9 \%$ あ゙っ た。それらのスポーツ外傷・障害で治癒までに一 番長くかかったものについては，スポーツ外傷は 中学生では足関節 $28.7 \% \cdot$ 高校生では同じく足 関節 $29.8 \%$ あ゙あた。スポーツ障害は中学生で は膝 $19.0 \%$ であり, 高校生では腰 $24.0 \%$ であっ た，小学生または中学生の時から継続しているス ポーツ障害があるかとの調査では，なしは $319 人$ 中 257 人, $85.6 \%$ あ゙り, 小学生からありは 4.1 \%, 中学生からありは $10.3 \%$ あった。

内山ら 6) は大学サッカー選手における現在の 競技生活に支障をきたしている障害とその発生学 年についての調査を報告している。 それによると 現在なんらかの支障となっている障害, 外傷の受 傷時期は中学で $24.8 \%$ 高校で $49.6 \%$ あった. その部位は足関節が最も多く，次いで膝関節，腰 部となっていた。思春期のスポーツ障害のなかに はスポーツ外傷が原因となっている例と, 本来の スポーツ障害, いわゆる過労性障害とがあり,
表-2 成長期体操選手のスポーツ外傷・障害

\begin{tabular}{|c|c|c|}
\hline & 男子 18 & 女子 15 \\
\hline 凖椎分離症 & 2 & 1 \\
\hline 腰痛症 & 11 & 6 \\
\hline 足関節痛 & 7 & 4 \\
\hline 膝痛 & 6 & 2 \\
\hline 手関節痛 & 4 & 1 \\
\hline 肘痛 & 1 & 1 \\
\hline 肘脱臼 & 0 & 2 \\
\hline 肩痛 & 1 & 2 \\
\hline 膝勒帯損傷 & 1 & 2 \\
\hline 膝蓋骨亜脱白 & 1 & 1 \\
\hline 足関節踝部骨折 & 2 & 2 \\
\hline
\end{tabular}

小・中学生のものが, その後のスポーツ活動にな んらかの影響を及ぼしている例が多い。その部位 は外傷では足関節，障害では膝関節・腰であるの が特徴である。

\section{主なスポーツ外傷}

\section{1. 足関節}

足関節捻挫のなかには再三繰り返し，慢性とな り，その後のスポーツ活動に支障をきたす例があ る7). 特に外側勒帯損傷の 3 度で正しく治療され なかった例に多い. 第 3 度の勒帯損傷の初期治療 には保存的と観血的があるが，保存的治療の適応 が大である．ギプスで完全固定するよりは，ブレ 一スで背屈・底屈はあまり制限しないでの固定が 良いようである。

中学生以上では勒帯損傷だけではなく, 関節軟 骨に損傷があることがある. 関節鏡検査 ${ }^{8)}$ などが 必要である。捻挫の繰り返しにより，関節の不安 定性だけでなくインピンジメント症候群として の, 距骨背側の骨棘形成, 後方の三角骨障害など が生じる例があり，観血的治療が考慮される．踝 部骨折では骨端線骨折があるので，捻挫との鑑別 が重要である。いずれにしろ足関節外傷は初期に 正しい治療がされないために，その後のスポーツ 活動に支障をきたす例があるので，この点十分な 注意が払われることが望まれる。 
表-3 骨・軟骨の障害 ( 関節周囲 )

\begin{tabular}{|c|c|c|c|c|}
\hline & & 小学生 & 中学生 & 高校生 \\
\hline \multirow[t]{2}{*}{ 腰椎 } & シュモール結節 & 2 & 2 & \\
\hline & 分離症 & 5 & 22 & 24 \\
\hline 骨盤 & 骨端炎 & & 22 & 6 \\
\hline \multirow[t]{4}{*}{ 膝 } & 離断性骨軟骨炎 & & 3 & 4 \\
\hline & オスグッド・シュラッテル病 & 17 & 141 & 23 \\
\hline & シンディングラルセン病 & 6 & & \\
\hline & 有痛性分裂膝蓋骨 & 4 & 12 & 7 \\
\hline \multirow[t]{4}{*}{ 足 } & 踵骨骨端症 & 16 & 13 & \\
\hline & 有痛性外頸骨 & 7 & 21 & 2 \\
\hline & 第1種子骨障害 & 4 & 3 & 4 \\
\hline & 有痛性三角骨 & & & 1 \\
\hline \multirow[t]{2}{*}{ 肘 } & 離断性骨軟骨炎 & 8 & 23 & 6 \\
\hline & 内側骨端線障害 & 8 & & \\
\hline \multirow[t]{2}{*}{ 肩 } & 骨端線障害 & 9 & & \\
\hline & 計 & 86 & 262 & 77 \\
\hline
\end{tabular}

表-4 主なスポーツ障害発生の割合

\begin{tabular}{|c|c|c|c|}
\hline & $\begin{array}{c}\text { 小学生 } \\
(\mathrm{n}: 572)\end{array}$ & $\begin{array}{c}\text { 中学生 } \\
(\mathrm{n}: 2035)\end{array}$ & $\begin{array}{c}\text { 高校生 } \\
\text { ( n : 1089) }\end{array}$ \\
\hline 脊椎分離症 & $0.9 \%$ & $1.6 \%$ & $1.3 \%$ \\
\hline 野 球 肘 & 13.3 & 6.5 & 1.5 \\
\hline 痛 & 5.6 & 0.7 & 3.6 \\
\hline 痛 & 3.3 & 5.1 & 5.1 \\
\hline $\begin{array}{l}\text { オスグッド, } \\
\text { シュラッテル病 }\end{array}$ & 6.2 & 6.9 & 1.3 \\
\hline 踵骨骨端症 & 5.4 & 0.9 & 0 \\
\hline 足 & 3.7 & 8.1 & 3.8 \\
\hline
\end{tabular}

\section{2. 前十字勒帯損傷}

前十字勒帯損傷は比較的若い人に多くみられ る.われわれの 996 例の手術例中 15 歳以下は 62 例 $6.2 \%$ 占めていた。 これらは女子の体操・バ スケットがほとんどであった. 女子体操選手 54 例 の年齢は 14 歳から 24 歳, 平均 17.1 歳で 16 歳が一 番多かった. 高校生が 27 例・大学生が 24 例で, 高 校生の方がやや多いのが特徴であった. 30例が試 合中，15例が試合前の練習で，残りの9例は練習 でのそれぞれ受傷であった。受傷機転は床・平均 台などでの着地の際であり，それほど激しい外力 が加わってのものではなかった.

前十字勒帯損傷は女子に多く, 受傷機転が着地
のような非接触性であるなどの特徴がある。この ことについては女性の前十字勒帯そのものが弱い のか, ホルモンの影響があるのか ${ }^{9)}$, 筋力の弱さ なのか, 骨盤の横径の増加による下肢のアライン メントの関係か 10), 勒帯損傷以前に小外傷が繰 り返しているために, 勒帯自体に顕微鏡的な損傷 が生じているためかなど種々の原因が考えられて いる.

\section{スポーツ障害}

思春期のスポーツ障害は上肢ではリトルリーグ 肩 (上腕骨近位骨端線離開), 野球肘としての内 側上顆, 时頭の骨端障害, 離断性骨軟骨炎・撓骨 遠位骨端線損傷などであり，下肢では膝障害・シ ンスプリント・疲労骨折, 腰部では腰痛症・尙椎 分離症などである.

これらのスポーツ障害の発生は発育の時期と深 い関係があり，われわれの年代別発生率の調查に その特徴が認められる。尙椎分離症は中学生に, 野球时は小学生高学年に, 肩関節痛は小学生と高 校生に, 膝痛は中学生と高校生に, オスグッド病 は小・中学生に発生率が高いなどである（表-3, 表-4). 


\section{女子のスポーツ障害}

思春期の女子は女性特有な体型が現れる時期で ある．第 2 次性徴が生じる時期である。このため スポーツ障害の発生も女性特有の要因に求められ ることがある．膝・肩・肘などの障害にみられる 11).

1. 膝関節痛・Anterior knee pain

膝関節前面の疼痛は思春期の女性によくみられ るスポーツ障害である。鑑別診断には炎症性・機 械的，その他などによるものが考えられるが，機 械的刺激によるものとして膝蓋骨覀脱臼・脱臼・ 膝蓋大腿関節障害 ( patellofemoral stress syndrome ）などがあり，女子に多い.

P-F障害は下肢のアラインメントの異常, すな わち, 前足部の回内 - 脛骨外側捻転 $\cdot \mathrm{Q}$ 角の増 大・大腿頝部前捻・内側広筋の萎縮などにより膝 蓋骨を外側にずらす過度の力がかかり, 関節面に 負荷が加わり症状が生じると考えられている11). これは女子体操・陸上などによくみられる.

\section{2. 肩関節痛}

思春期の女性では関節の弛緩性・筋力の低下が 肩関節痛を引き起こすもとになる.

\section{3 . 肘障害}

女子は肘外反が強く ( carrying angle), 勒帯 の弛緩性が男子より大であるので, 体操のように 荷重のかかる種目では外側への負荷が強くなる. その結果, 離断性骨軟骨炎が起き, 関節遊離体が 生じることがある.

\section{4. 手関節障害}

女子体操では床・跳馬などの着地で手関節の背 屈を繰り返すことにより, 関節の柔軟性が大きい ことも原因となり，撓骨背側と手根骨とがぶつか り合い，いわゆる impingement症候群としての 疼痛が起きやすい，撓骨遠位骨端線骨折を起こす こともある12）(図-1）。

\section{予防について}

思春期は身体の発育・発達が盛んな時期であ

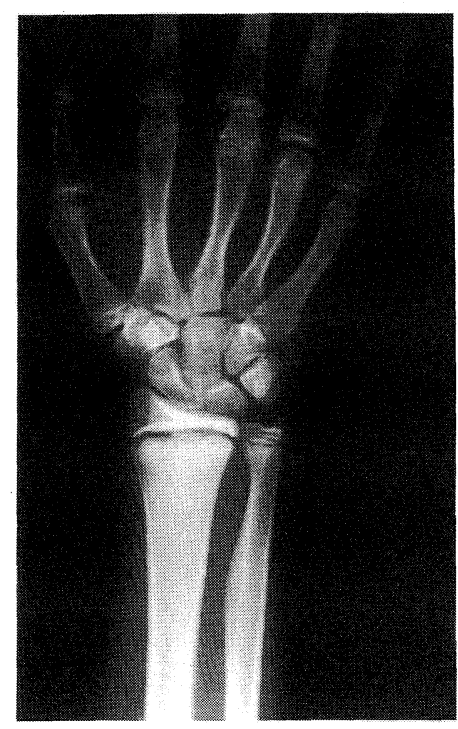

図-1 14 歳 女子 体操選手 （右手関節 撓骨遠位骨端線骨折）

る。そのうえ発育・発達の程度に個人差がある。 同じ年齢でも発育の程度には差がある。スポーツ を行う際には，この発育の程度を考慮しなければ ならない.なぜならば，スポーツ障害は骨・関節 など発育している部位は外力に対しての抵抗が弱 いからである。関節軟骨・骨端線はもちろんであ るが, 勒帯・腱・骨も成長過程では十分な強度に はなっていない，スポーツ活動での繰り返しの負 荷が局所に過度にかかると過労性の障害が発生す る。これを䂆方するには負荷の軽減を図れば良い わけである. 当然, 練習量が問題になるが, 練習 の質も深く関係している，個人の体力・体型・既 往症も考慮の対象になる。

文部省の調査によればスポーツ障害の発生原因 は選手側の回答で第 1 位は長時間の練習であり, 次いではレギュラーに対する執着であった。一方, 指導者側の回答で第 1 位は選手側と同様である が，次ぎは非科学的トレーニングであった．われ われの中学生・高校生についてのスポーツ外傷・ 障害の発生原因の調査でも，不注意・練習のしす ぎが多かった13）(表-5).

スポーツ外傷にしてもスポーツ障害にしてもそ 
表-5 スポーツ外傷・障害の発生原因

\begin{tabular}{l|c|c}
\hline & $\begin{array}{c}\text { 中学全体 } \\
(\mathrm{n}: 1726)\end{array}$ & $\begin{array}{c}\text { 高校全体 } \\
(\mathrm{n}: 2063)\end{array}$ \\
\hline 疲労 & 7.9 & 20.5 \\
睡眠不足 & 2.1 & 1.7 \\
不注意 & 24.4 & 21.2 \\
急に練習を始めた & 9.5 & 11.4 \\
練習のしすぎ & 14.5 & 16.9 \\
むずかしい練習 & 3.5 & 3.2 \\
天気が悪かった & 1.6 & 1.5 \\
グラウンドや体育館が & 4.7 & 4.1 \\
悪かった & 0.8 & 0.7 \\
ルールを守らなかった & 2.2 & 1.9 \\
用具が原因 & 6.1 & 16.1 \\
不可抗力 & 16.2 & 17.8 \\
わからない & 12.7 & 13.7 \\
その他 & 19.2 & 2.2 \\
無回答 & & \\
\hline
\end{tabular}

の䂆方がなにより重要であるが，完全に予防する

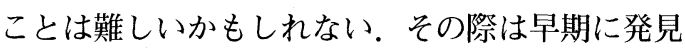
し,適切な処置をすることも大切であり,そのため には指導者に対しての正しい教育も必要であろう。

\section{文献}

1) Sharp NCC: Fitness, exercise and sport in children, Sports Exercise and Injury, $1996 ; 2$ : 11 121.

2) 村田光範：日本人小児の発育発達の生理学的特徵 一日中の比較から。臨床スポーツ医学, 1988； $5: 979 \sim 984$.

3) Micheli LL : Overuse injuries in children's sports. The growth factor, Orthop. Cli North Am., $1983 ; 14: 337 \sim 359$.

4）高澤晴夫：発育期のスポーツ外傷・障害の予防に ついて. 臨床スポーツ医学, $1988 ; 5: 985 \sim 990$.

5）文部省：運動部活動の在り方に関する調査研究 報告書, 平成 9 年 12 月.

6）内山秀一, 他：大学サッカー選手における現在の 競技生活に支障をきたしている障害とその発生率. 東海大学スポーツ医科学雑誌, $1998 ; 10 ： 18 〜 23$. 7) Smith RW, Reischl SF : Treatment of ankle sprains in young athletes. Am J Sports Med, $1986 ; 14: 465 \sim 471$.

8) Ferkel RD, Karzelr RP, et al. : Arthroscopic treatment of anterolateral impingement of the ankle. Am J Sports Med, $1991 ; 19: 440$ $\sim 446$.

9) Yu WD, Liu SH, et al. : Female sex hormones influence the cellular metabolism of the human anterior cruciate ligament (ACL), FortyFourth Annual Meeting of the Orthopaedic Research Society, 1998.

10) Zelisko JA, Noble HB, Porter M : A comparison of men's and women's professional basketball injuries. Am J Sports Med, 1982 ; 10 : 297 299 .

11) Ireland ML : Special concerns of the female athlete, Sports Injuries, Fu FH, Stone DV. eds. Athletic Sports Injuries, 1994:153 187.

12）高澤晴夫, 他: 発育期女子体操選手のスポーツ外 傷一とくに手関節骨端線損傷と前十字勒帯損傷 について.臨床スポーツ医学, $1990 ; 7$ : 1233〜 1237.

13）高澤晴夫：小児にスポーツ障害. 日本医師会雑 誌, $1988 ； 101 ： 1499 \sim 1502$. 